\title{
Toxic Bait as an Alternative Tool in the Management of Spodoptera frugiperda in Second Corn Crops
}

\author{
Wagner Justiniano ${ }^{1}$, Marcos Gino Fernandes ${ }^{1} \&$ Josué Raizer $^{1}$ \\ 1 Programa de Pós-Graduação em Entomologia e Conservação da Biodiversidade, Faculdade de Ciências \\ Biológicas e Ambientais, Universidade Federal da Grande Dourados, Dourados, MS, Brazil \\ Correspondence: Wagner Justiniano, Programa de Pós-Graduação em Entomologia e Conservação da \\ Biodiversidade, Faculdade de Ciências Biológicas e Ambientais (FCBA), Universidade Federal da Grande \\ Dourados (UFGD), Dourados, MS, Brazil. E-mail: wagner.justiniano@bayer.com
}

Received: December 16, 2020

doi:10.5539/jas.v13n3p102
Accepted: January 20, $2021 \quad$ Online Published: February 15, 2021

URL: https://doi.org/10.5539/jas.v13n3p102

\begin{abstract}
Managing the fall armyworm (FAW), Spodoptera frugiperda (J.E. Smith, 1797), has been increasingly difficult owing to the increase in individual resistance to insecticides and genetically modified Bacillus thuringiensis (Bt) plants. This study used the attracting and killing method to control FAW adults in the field by spraying Noctovi ${ }^{\circledR}$ with methomyl insecticide. The experiments were conducted in commercial cornfields, non-Bt and Bt crops, over two agricultural years (2018 and 2019) at eight sites distributed in three cities located in the south of Mato Grosso do Sul State, Brazil. The following six insecticide treatments were used: spraying in continuous bands spaced every 100, 50, and $25 \mathrm{~m}$; intermittent spraying every $25 \mathrm{~m}$; control (without insecticide application); and spraying the entire area with insecticide (positive control). Food bait associated with the insecticide molecule was applied to the crop at vegetative stages V1 and V3, and the adult population size and level of leaf damage caused by the caterpillars (assessed via the Davis scale) were evaluated. The application of toxic bait in bands with spacing less than or equal to $50 \mathrm{~m}$ significantly reduced the percentage of damage to the plants, with the effect stronger in Bt crops. We suggest that the control of FAW adult populations would be more efficient if the attracting and killing technique was incorporated in integrated pest management programs for second corn crops.
\end{abstract}

Keywords: fall armyworm, adult control, Davis scale, spraying in bands, semiochemical

\section{Introduction}

Corn Zea mays L. is one of the main crops worldwide, and in Brazil, it is grown throughout the country using different technological systems and levels of technology use (Campanha et al., 2012).

Among the pests that attack corn, the fall armyworm (FAW), Spodoptera frugiperda (J.E. Smith, 1797) (Lepidoptera: Noctuidae), is the most important, causing irreversible damage. In Brazil, productivity losses due to this pest can reach $60 \%$ depending on the genotype, plant developmental stage, and growing season (Carnevalli \& Florcovski, 1995; Cruz \& Turpin, 1982; Cruz et al., 1999).

Eggs deposited by the adult insects are seen immediately after the emergence of the first leaves on the plants (Toscano et al., 2012). After emergence, even though the caterpillar feeds on corn during all its growth stages, it prefers the young plants (Gallo et al., 2002).

In Brazil, chemical control and the use of genetically modified Bacillus thuringiensis (Bt) plants are the main strategies for the management of several pest species (Costa \& Queiroz, 2014). However, S. frugiperda has not been easy to control, and some insecticides and Bt plants currently available on the market have failed in this task (Bernardi \& Omoto, 2018).

The intensive use of insecticides has led to the development of generalized and multiple resistance, and severe negative impacts on non-target species, including natural enemies, parasitoids, and pollinators (Liu et al., 2017).

Bt plants have provided a new control strategy for FAW. However, the bioecological characteristics of the pest in some regions, such as high reproductive potential, relatively short biological cycle, and polyphagia, associated with the scenario of overlap and succession of host plant crops ("green bridge"), have made FAW populations vulnerable to the high selection pressure of insecticides and Bt proteins. This provides a favorable scenario for increased resistance and subsequent compromise of control strategies (Bernardi \& Omoto, 2018). 
Some pests have evolved resistance to both insecticides and Bt plants, with FAW being the leading example, showing resistance to the Cry1F protein expressed in corn in several countries (Farias et al., 2014; Lu et al., 2010; Santos-Amaya et al., 2015; Storer et al., 2010; Tabashnik et al., 2013) and in Bt plants that express the proteins Cry1A.105 + Cry2Ab2 (Souza et al., 2019).

Thus, the effective implementation of resistance management strategies is essential for ensuring the durability of any control strategy for S. frugiperda. One alternative is to target adults of pest species using semiochemicals, such as pheromones or volatiles from pest host plants (Witzgall et al., 2010). However, one of the limitations to the use of sex pheromones is that they only attract adult males of the target species, whereas food baits composed of vegetable volatiles attract both sexes of various lepidopteran species, which can significantly decrease the adult populations, oviposition, and subsequent larval populations (Del Socorro et al., 2010a; Del Socorro et al., 2010b; Su et al., 2001).

Semiochemicals can be an efficient alternative control method and tool for managing resistance development. Recently, studies conducted under controlled laboratory conditions have demonstrated the possibility of using commercial semiochemicals associated with chemical insecticide molecules for the management of FAW adults (Justiniano \& Fernandes, 2020).

Noctovi ${ }^{\circledR}$ is composed of oleoresins and sugars. The oleoresins release volatiles that attract moths at great distances and the sugars stimulate the moths to feed, also ingesting the lethal insecticide that is associated. Thus, we aimed to evaluate the viability of a new tool for the integrated pest management of second corn crops via the application of the Noctovi ${ }^{\circledR}$ commercial product with methomyl active insecticide to control FAW adults and reduce caterpillar infestation under real field conditions.

\section{Materials and Methods}

\subsection{Study Location and Experimental Plots}

The experiments were conducted in commercial areas producing second corn crops in three municipalities in the of Mato Grosso do Sul State, Brazil, in eight locations (plots/blocks) in 2018 and 2019 (Table 1).

Table 1. General characteristics of sampling sites for the field experiment on the effect of toxic bait on the management of $S$. frugiperda adults in second corn crops with or without Bt plants. Mato Grosso do Sul, Brazil

\begin{tabular}{lllllll}
\hline Site & Crop & County & Farm & Latitude & Longitude & Seeding \\
\hline 1 & 2018 & Dourados & Esperança & $-22^{\circ} 01^{\prime} 10^{\prime \prime} \mathrm{S}$ & $-54^{\circ} 55^{\prime} 33^{\prime \prime} \mathrm{W}$ & $2 / 23 / 2018$ \\
2 & 2018 & Dourados & Esperança & $-22^{\circ} 04^{\prime} 43^{\prime \prime} \mathrm{S}$ & $-54^{\circ} 55^{\prime} 27^{\prime \prime} \mathrm{W}$ & $3 / 4 / 2018$ \\
3 & 2018 & Dourados & Esperança & $-22^{\circ} 01^{\prime} 47^{\prime \prime} \mathrm{S}$ & $-54^{\circ} 55^{\prime} 50^{\prime \prime} \mathrm{W}$ & $3 / 19 / 2018$ \\
4 & 2018 & Dourados & Esperança & $-22^{\circ} 02^{\prime} 23^{\prime \prime} \mathrm{S}$ & $-54^{\circ} 56^{\prime} 00^{\prime \prime} \mathrm{W}$ & $3 / 20 / 2018$ \\
5 & 2019 & Douradina & Boa Vista & $-22^{\circ} 01^{\prime} 04^{\prime \prime} \mathrm{S}$ & $-54^{\circ} 32^{\prime} 27^{\prime \prime} \mathrm{W}$ & $1 / 27 / 2019$ \\
6 & 2019 & Douradina & Boa Vista & $-22^{\circ} 02^{\prime} 00^{\prime \prime} \mathrm{S}$ & $-54^{\circ} 34^{\prime} 50^{\prime \prime} \mathrm{W}$ & $2 / 8 / 2019$ \\
7 & 2019 & Rio Brilhante & Flor do Cerrado & $-21^{\circ} 40^{\prime} 50^{\prime \prime} \mathrm{S}$ & $-54^{\circ} 38^{\prime} 09^{\prime \prime} \mathrm{W}$ & $2 / 25 / 2019$ \\
8 & 2019 & Rio Brilhante & Flor do Cerrado & $-21^{\circ} 40^{\prime} 30^{\prime \prime} \mathrm{S}$ & $-54^{\circ} 38^{\prime} 37^{\prime \prime} \mathrm{W}$ & $2 / 26 / 2019$ \\
\hline
\end{tabular}

The commercial areas were planted with Bt hybrid VT PRO $3^{\circledR}$, which expresses the proteins Cry1A.105 and Cry2Ab2 for protection against caterpillars, Cry3Bb1 against corn rootworm larva, and CP4-EPSPS that provides tolerance to the glyphosate herbicide, and non-Bt hybrid RR2 ${ }^{\circledR}$, which expresses CP4-EPSPS that is used for planting a structured refuge (CIB, 2012).

The corn was sown with $50 \mathrm{~cm}$ spacing between the rows, with 3 to 3.2 seeds per meter, resulting in a population between 60,000 and 64,000 plants ha ${ }^{-1}$. The control of weeds and non-target insect species in the study areas was undertaken by farmers without distinguishing between treatments and crop technologies.

The experiments were performed in commercial plots of second corn crops, with each replicate using both VT $\mathrm{PRO}^{\circledR}$ and RR2 ${ }^{\circledR}$ technologies. Each experimental plot, located within the producer's commercial area, consisted of 1 ha spaced laterally every $10 \mathrm{~m}$ (border). The experimental block was composed of 12 plots, with six Bt and six non-Bt plots (Figure 1).

The experiment was repeated for the 2018 and 2019 crops, with four locations each year. One of the following treatments was applied to each plot: treatment 1 , continuous spraying spaced every 100 meters; treatment 2 , continuous spraying spaced every $50 \mathrm{~m}$; treatment 3, continuous spraying spaced every $25 \mathrm{~m}$; treatment 4 , 
intermittent spraying spaced every $25 \mathrm{~m}$; treatment 5, no spray (negative control); and treatment 6 , insecticide application in the entire area (positive control).

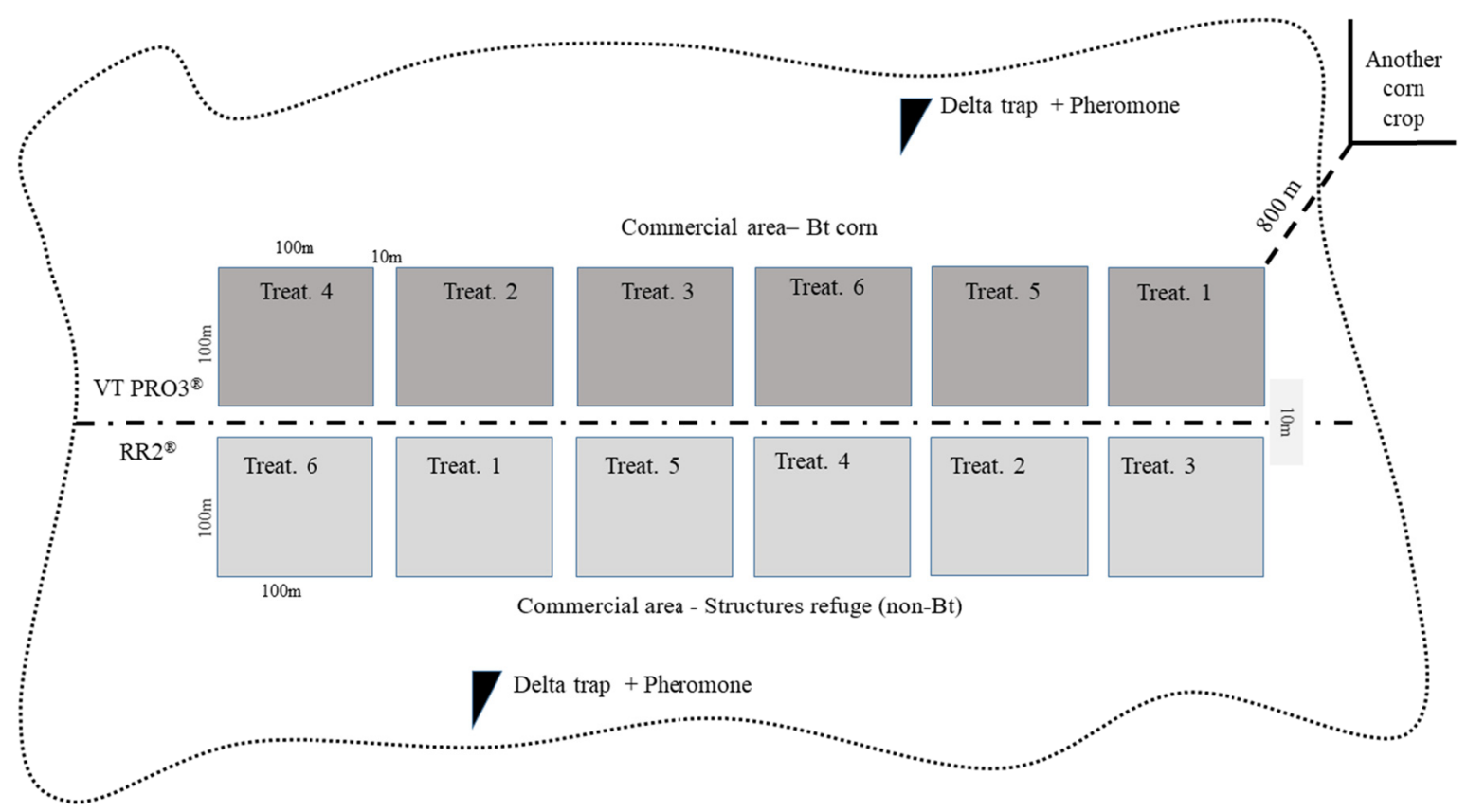

Figure 1. Illustrative schema of the experimental design of one of the sites (block) containing the different treatments of Bt and non-Bt corn. Mato Grosso do Sul, Brazil

\subsection{Toxic Bait Application}

Toxic bait was applied at $1 \mathrm{~L} \mathrm{ha}^{-1}$ in the treatments and contained the Noctovi ${ }^{\circledR} 43 \mathrm{sb}$ commercial food (ISCA, Brazil) bait with $20 \mathrm{~mL} \mathrm{ha}^{-1}$ of the methomyl active ingredient insecticide (Lannate ${ }^{\circledR}$ BR commercial product) at a $2 \%$ volume per spray rate volume. We used this combination because it was previously proven effective in combating FAW adults, causing up to $100 \%$ mortality in laboratory conditions (Justiniano \& Fernandes, 2020).

At the time of sowing, two "Delta" traps were installed $1.5 \mathrm{~m}$ above the ground, one in the area next to the Bt corn plots and the other in the non-Bt corn plots. The bottom of the traps contained a sticky coating and the synthetic Bio Spodoptera sex pheromone for FAW (ChemTica International S.A.), consisting of a mixture of (Z)-7-dodecenyl acetate, (Z)-9-tetradecenyl acetate, and (Z)-11-hexadecenyl acetate. The pheromone was hung from the top of the trap and remained active for 30 days.

Food bait containing the insecticide was applied twice. The first application was between 8 and 12 days after crop emergence (DAE) (vegetative stage V1) and the second was between 17 and 21 DAE (vegetative stage V3).

A spraying device mounted on a Suzuki ${ }^{\circledR} 160 \mathrm{cc}$ quadricycle with controlled speed was used for treatment applications. Continuous application in bands was performed with a Branco ${ }^{\circledR}$ sprayer powered by gasoline, which was equipped with a hydraulic circuit, pressure gauge for pressure calibration, and four hydraulic nozzles spaced every $0.5 \mathrm{~m}$ positioned on the corn lines and at a height of $0.3-0.5 \mathrm{~m}$ above the plants. The intermittent application was performed with a PRECISA ${ }^{\circledR}$ brand sprayer, mounted under the same motorized quadricycle, and the sprayer was calibrated to a 1 second application after 3 seconds without application, with a closed pressure-regulating valve and the same hydraulic circuit, pressure gauge, and four hydraulic nozzles as that of the continuous sprayer (Monteiro, 2017).

The toxic bait application rate was approximately $1 \mathrm{~L} \mathrm{ha}^{-1}$ and XR80.03 tips without sieves (Spraying Systems, Cia) were used. The number of open tips during applications varied with the width of the application bands: treatment 1 was performed with four open tips, treatment 2 used two open tips, treatment 3 had only one open tip, and treatment 4 had four tips that applied the mixture only $25 \%$ of the time. 
The equipment speed was $10 \mathrm{~km} \mathrm{~h}^{-1}$ and the hydraulic circuit pressure was constant between 1.5 and 1.8 bar, resulting in a flow rate between 0.42 and $0.45 \mathrm{~L} \mathrm{~min}^{-1}$, which was lower than that indicated in the manufacturer's manual where the tests were performed with water.

The commercial food attractive used, Noctovi ${ }^{\circledR} 43 \mathrm{sb}$, has different characteristics depending on the application modality (applied pure or together with the insecticide without adding water), such as the density and viscosity of the liquid. The mists generated from the applications deposited 1 to 3 drops per $100 \mathrm{~cm}^{2}$ at spots ranging between 1 and $1.5 \mathrm{~cm}$ in diameter.

Treatment 5 (negative control) did not receive any application of insecticide or toxic bait for the management of FAW, whereas in treatment 6 , insecticide containing methomyl at a commercial dose of $1.2 \mathrm{~L} \mathrm{ha}^{-1}$ diluted in water was applied to the entire area at a rate of $150 \mathrm{~L} \mathrm{ha}^{-1}$. For this, we used model XR110.02 tips with sieves spaced every $0.5 \mathrm{~m}$ at a height of $0.5 \mathrm{~m}$ above the plants and with a pressure of approximately 3 bar, together with toxic bait application twice at the V1 and V3 stages.

Meteorological conditions, especially rainfall, were monitored throughout the experiment and toxic bait applications because rainfall can drastically reduce the residual persistence of the bait if it occurs soon after application. At least $48 \mathrm{~h}$ without rain after application was required to isolate this variable. If this did not occur, all treatments were reapplied.

\subsection{Data Collection}

The $S$. frugiperda population was monitored weekly by collecting and identifying the adults captured in the sticky bottom of the Delta traps containing sex pheromones. The sticky bottom was replaced during collection to avoid catch failure in the following week.

The damage caused by the attack of caterpillars on corn leaves was quantified according to the damage scale described by Davis, Ng, and Williams (1992), which provides plant damage scores depending on the type, size, and shape of the damage caused to the leaves by FAWs (Table 2). Evaluations occurred at the following five stages (Hanway, 1971; Ransom \& Endres, 2014): V1 corresponded to the first leaf; V2 was characterized by two completely expanded leaves, where the insertion ring of the sheath is clearly defined; and V3, V4, and V6 corresponded to three, four, and six completely expanded leaves, respectively.

Table 2. Visual classification scale to estimate the damage to corn leaves caused by the feeding of fall armyworm caterpillars (Spodoptera frugiperda) (adapted from Davis et al., 1992)

\begin{tabular}{|c|c|c|}
\hline \multirow{2}{*}{ Score } & \multicolumn{2}{|c|}{ Description } \\
\hline & 7 days & 14 days \\
\hline 0 & No visible damage. & No visible damage. \\
\hline 1 & Only pinhole lesions present on whorl leaves. & Only pinhole lesions present on whorl leaves. \\
\hline 2 & Pinholes and small circular lesions present on whorl leaves. & Pinholes and small circular lesions present on whorl leaves. \\
\hline 3 & $\begin{array}{l}\text { Pinholes, small circular lesions, and a few small, elongated } \\
\text { (rectangular-shaped) lesions up to } 1.3 \mathrm{~cm}\left(1 / 2^{\prime \prime}\right) \text { in length present } \\
\text { on whorl and furl leaves. }\end{array}$ & $\begin{array}{l}\text { Small, circular lesions and a few small, elongated } \\
\text { (rectangular-shaped) lesions up to } 1.3\left(1 / 2^{\prime \prime}\right) \text { in length present on } \\
\text { whorl and/or furl leaves. }\end{array}$ \\
\hline 4 & $\begin{array}{l}\text { Small, elongated lesions present on whorl leaves and a few } \\
\text { mid-sized elongated lesions of } 1.3-2.5 \mathrm{~cm}\left(1 / 2-1^{\prime \prime}\right) \text { in length present } \\
\text { on whorl and/or furl leaves. }\end{array}$ & $\begin{array}{l}\text { Several small- to mid-sized elongated lesions of } 1.3-2.5 \mathrm{~cm} \\
\left(1 / 2-1^{\prime \prime}\right) \text { in length present on a few whorl and furl leaves. }\end{array}$ \\
\hline 5 & $\begin{array}{l}\text { Small, elongated lesions and several mid-sized elongated lesions } \\
\text { present on whorl and furl leaves. }\end{array}$ & $\begin{array}{l}\text { * Several large elongated lesions greater than } 2.5 \mathrm{~cm}\left(1^{\prime \prime}\right) \text { in length } \\
\text { present on a few whorl and furl leaves and/or a few small- to } \\
\text { mid-sized uniform to irregularly shaped holes (basement membrane } \\
\text { consumed) eaten from the whorl and/or furl leaves. }\end{array}$ \\
\hline & Small- and mid-sized elongated lesions plus a few large elongated & * Several large elongated lesions present on several whorl and furl \\
\hline 6 & $\begin{array}{l}\text { lesions of greater than } 2.5 \mathrm{~cm}\left(1^{\prime \prime}\right) \text { in length present on whorl } \\
\text { and/or furl leaves. }\end{array}$ & $\begin{array}{l}\text { leaves and/or several large uniform to irregularly shaped holes } \\
\text { eaten from furl and whorl leaves. }\end{array}$ \\
\hline 7 & $\begin{array}{l}\text { Many small- and mid-sized elongated lesions present on whorl } \\
\text { leaves plus several large elongated lesions present on furl leaves. }\end{array}$ & $\begin{array}{l}\text { Many elongated lesions of all sizes present on several whorl and } \\
\text { furl leaves plus several large uniform to irregularly shaped holes } \\
\text { eaten from the whorl and furl leaves. }\end{array}$ \\
\hline 8 & $\begin{array}{l}\text { Many small- and mid-sized elongated lesions present on whorl } \\
\text { leaves plus many large elongated lesions on the furl leaves. }\end{array}$ & $\begin{array}{l}\text { Many elongated lesions of all sizes present on most whorl and furl } \\
\text { leaves plus many mid- to large-sized uniform to irregularly shaped } \\
\text { holes eaten from the whorl and furl leaves. }\end{array}$ \\
\hline 9 & $\begin{array}{l}\text { Many elongated lesions of all sizes on whorl and furl leaves plus a } \\
\text { few uniform to irregularly shaped holes (basement membrane } \\
\text { consumed) eaten from the base of the whorl and/or furl leaves. }\end{array}$ & completely destroyed. \\
\hline
\end{tabular}

Note. ${ }^{*}$ Scores 5 and 6 adjust for feeding damage caused by migratory mid-instar larvae. 
The evaluations started before the first application and continued during the initial vegetative period, which was critical for the culture owing to the attack of the FAW. A total of 10 points were sampled per replicate (each point was composed of 10 plants in sequence, 100 plants per replicate), during vegetative stages V1, V2, V4, and V6 (7-12, 12-15, 20-24, and 28-32 DAE, respectively). The total number of plants evaluated was 38,400, being 100 plants per replicate $\times 4$ evaluations per site $\times 6$ treatments per site $\times 2$ technologies per site $\times 4$ evaluations $\times 2$ years.

\subsection{Data Analysis}

The experiments were conducted in blocks with six treatments, two technologies (Bt and non-Bt corn), eight replicates (local), and two years, and were tested at four sites each year. Data normality was tested to assess compliance with analysis of variance (ANOVA) assumptions. The treatment means were compared at a significance level of 5\% ( $\mathrm{p}<0.05)$ using Tukey's test. All analyses were performed in the R language (R Core Team, 2019), and the partial residues of the multifactorial ANOVA were obtained using the car package (Fox \& Weisber, 2019).

\section{Results}

During the study, 2460 FAW adults were captured in areas cultivated with second corn crops, with 1218 and 1242 on $\mathrm{Bt}$ and non-Bt corn, respectively. Moths were present during all the initial growth stages of the crops and had similar population dynamics, regardless of the applied treatment. However, there was a slight population increase in stages V4 and V6, although this was not statistically different. The total number of individuals, mean (dispersion), on Bt and non-Bt corn was as follows: V1, 288 (36) and 314 (39.25); V2, 300 (37.5) and 298 (37.25); V4, 326 (40.75) and 309 (38.62); and V6, 304 (38) and 321 (40.12), respectively (Figure 2).

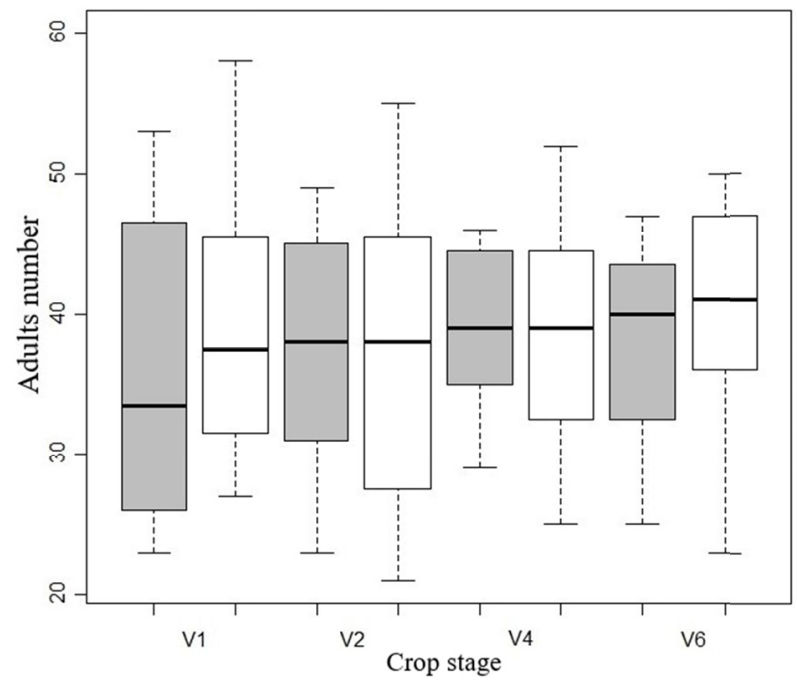

Figure 2. Population fluctuation of $S$. frugiperda adults in second corn crops, median and data dispersion in Bt (gray column) and non-Bt (white column) crops during the initial vegetative stages during management using food bait at eight sites. Mato Grosso do Sul State, Brazil in the agricultural year 2018-2019

The distribution of the Davis scale scores, with mean and amplitude transformed and equalized using partial residuals, representing that part of the variation indicating the effect of a variable in a multiple or multifactorial model excluding the effects of other variables, showed significant differences $(\mathrm{p}<0.001)$ among years $\left(\mathrm{F}_{1,3823}=\right.$ 165.93), technologies $\left(F_{1,3823}=1,322.44\right)$, and plant stages $\left(F_{3,3823}=1932.37\right)$ (Figure 3 ), and the damage caused by FAW larvae attacks during the second harvest in 2018 was more marked than that in 2019 (Figure 3A).

When comparing technologies, Bt plants showed much less damage than non-Bt plants, demonstrating that the proteins Cry1A.105 and 2Ab2 present in Bt plants provided partial protection to the corn plants from FAW attacks (Figure 3B). Regarding the plant developmental stages, the caterpillars developed as the plants grew, consuming more leaf area and increasing the damage. Infestations increased owing to overlapping generations within the same site (Figure 3C). 

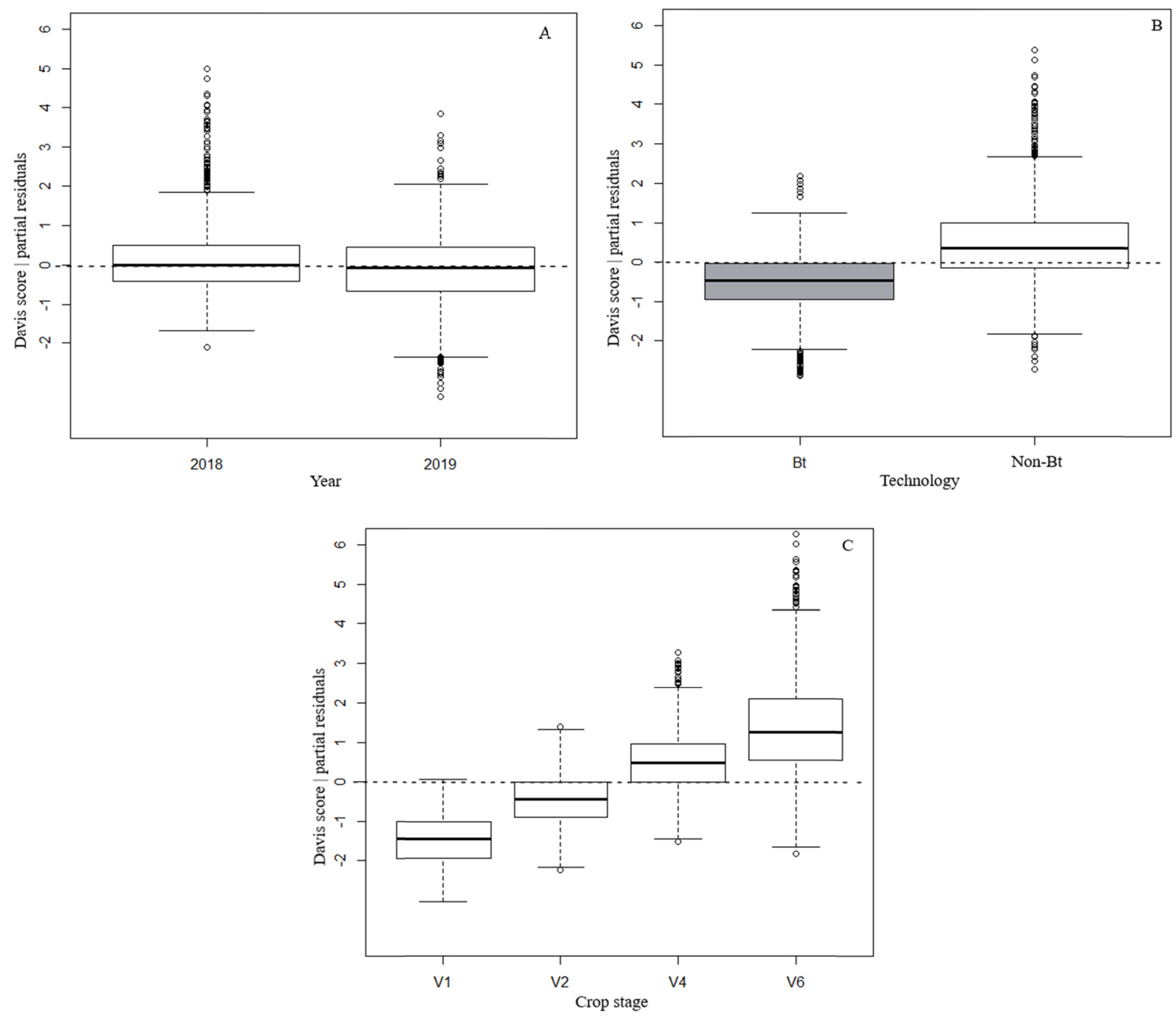

Figure 3. Partial residuals in a multifactorial analysis of variance for the effects of year (A), technology (B), and crop stage $(\mathrm{C})$ variables on leaf damage (Davis scale) in corn crops. Mato Grosso do Sul State, Brazil in the agricultural year 2018-2019

Considering the toxic bait treatments, grouping the different stages of the culture, with and without Bt plants, those sprayed in continuous bands spaced every 50 and $25 \mathrm{~m}$ (treatments 2 and 3) did not differ from those spaced every $25 \mathrm{~m}$ with intermittent application (treatment 4). However, there were differences among treatments 1 (spraying on a continuous band spaced every $100 \mathrm{~m}$ ), 5 (no spraying, control), and 6 (insecticide application over the entire area). Mean differences greater than 0.5 were observed in the partial residuals of treatments when comparing treatments 5 and 6 and treatments 1 and 6 (Figure 4). 

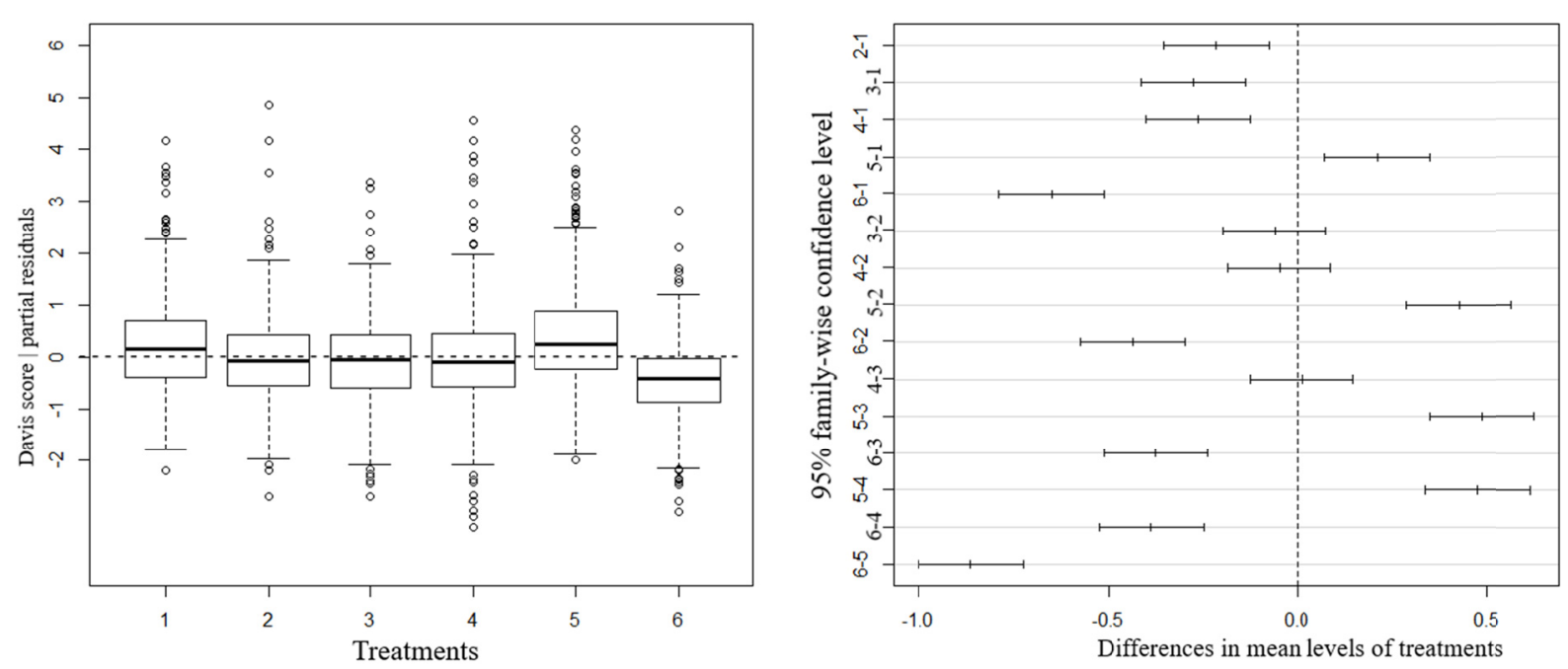

Figure 4. Partial residuals for Davis scale scores in treatments and differences in average treatment levels. Mato Grosso do Sul State, Brazil in the agricultural year 2018-2019

Treatments 2, 3, and 4 did not differ from each other, showing intermediate leaf damage. The control plants (treatment 5) had the highest damage levels, similar to treatment 1 . Moreover, the positive control (treatment 6 ) had the lowest damage levels (Figure 5).

The Davis scale scores were classified by damage: mild $(\geq 3)$, moderate $(\geq 5)$, and severe $(\geq 7)$; vegetative stage of corn; Bt and non-Bt corn; and the respective treatments (Figure 5 and Table 3). For non-Bt corn, treatments 2, 3 and 4 did not differ significantly from each other regardless of the culture stage. In the control treatment (treatment 5), the moderate damage caused by FAW was significantly higher than that in treatments 2, 3, 4, and 6 in the non-Bt cultivation for V4 and V6 stages using the same treatments.
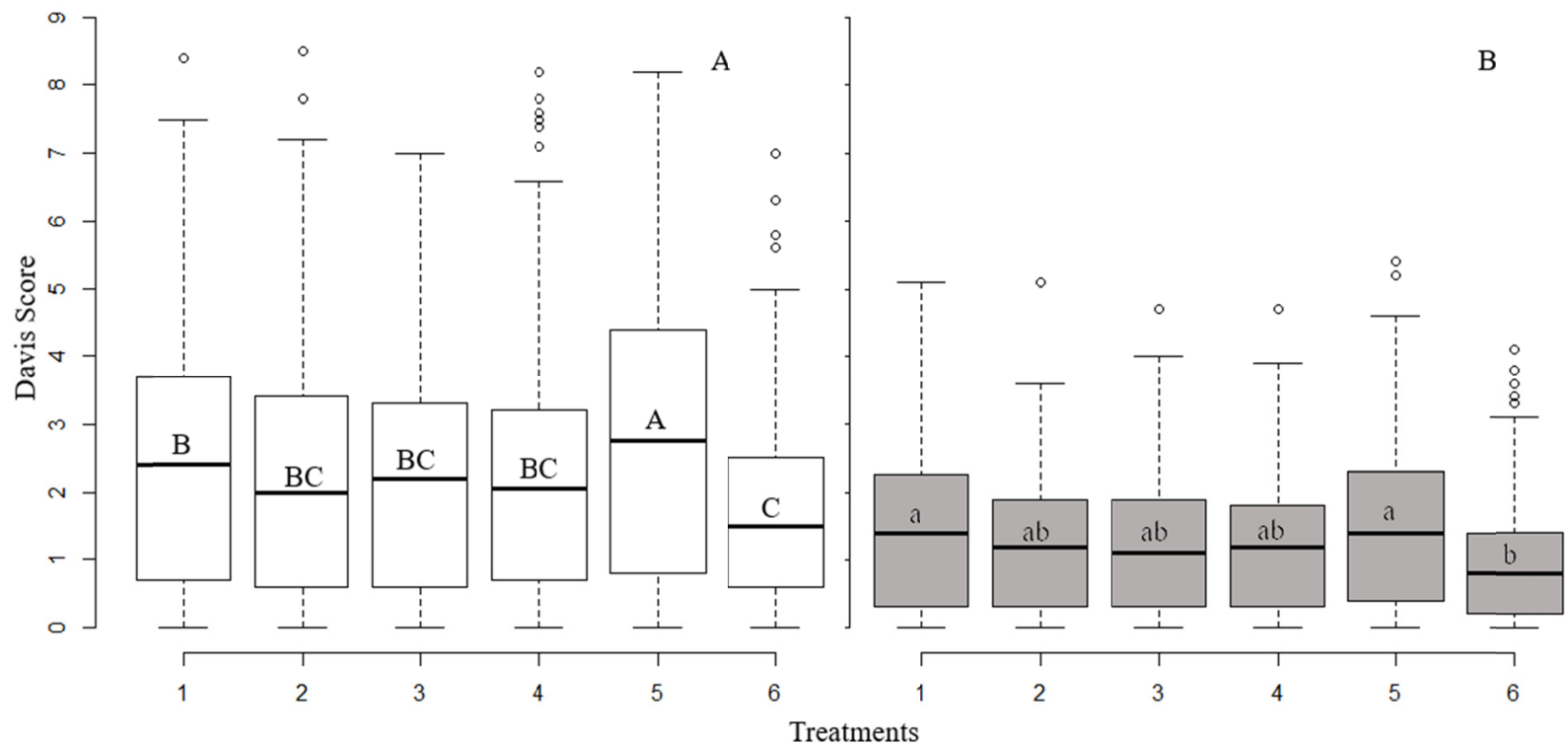

Figure 5. Dispersion and median for the Davis scale scores of treatments non-Bt (A) and Bt (B) owing to the attack and feeding of $S$. frugiperda caterpillars on genetically modified corn planted in the second harvest in the state of Mato Grosso do Sul State, Brazil in the agricultural year 2018-2019

In Bt corn, even with minor damage in the control treatment compared to that in the control treatment of non-Bt corn, the use of toxic bait significantly contributed to damage reduction, especially in treatments with $25 \mathrm{~m}$ bands (continuous or intermittent) considering mild and moderate damage. 
Treatments 2, 3, 4, and 6 yielded similar results regarding the percentage of mild damage in the V2 stage and moderate damage in the V4 and V6 stages. Toxic bait applied every 50 and $25 \mathrm{~m}$, continuously and intermittently for V4 and every $25 \mathrm{~m}$ for V6, showed similar damage to those in the positive control (treatment 6). Meanwhile, treatment 1 showed similar results to those in the control treatment for Bt corn plots and differed in plots without Bt plants only during the V4 stage, having a higher percentage of mild and moderate damage (Table 3 ).

Table 3. Percentage of Davis scale scores (mean \pm standard error) with technology, treatment, vegetative stage, and intensity of damage from the attack and feeding of $S$. frugiperda caterpillars on genetically modified corn grown during the second crop in Mato Grosso do Sul State, Brazil in the agricultural year 2018-2019

\begin{tabular}{|c|c|c|c|c|c|c|c|c|c|c|}
\hline \multirow{3}{*}{\multicolumn{2}{|c|}{ Technology/Treatments }} & \multicolumn{9}{|c|}{ Vegetative stages/Davis scale (scores) $^{(1)}$} \\
\hline & & \multirow{2}{*}{$\begin{array}{l}\overline{\mathrm{V} 1} \\
\geq 3\end{array}$} & \multicolumn{2}{|c|}{ V2 } & \multicolumn{3}{|c|}{$\mathrm{V} 4$} & \multicolumn{3}{|c|}{ V6 } \\
\hline & & & $\geq 3$ & $\geq 5$ & $\geq 3$ & $\geq 5$ & $\geq 7$ & $\geq 3$ & $\geq 5$ & $\geq 7$ \\
\hline \multirow{6}{*}{$\begin{array}{l}\vec{m} \\
\stackrel{0}{0} \\
\stackrel{0}{z}\end{array}$} & $100 \mathrm{~m}$ continuously & $3.25 \pm 0.45 \mathrm{~A}$ & $38.63 \pm 10.56 \mathrm{AB}$ & $3.13 \pm 2.16 \mathrm{AB}$ & $65.63 \pm 9.50 \mathrm{~B}$ & $25.13 \pm 4.99 \mathrm{~B}$ & $1.75 \pm 1.01 \mathrm{~B}$ & $76.25 \pm 6.04 \mathrm{AB}$ & 3 $53.25 \pm 7.87 \mathrm{AB}$ & $327.00 \pm 6.28 \mathrm{AB}$ \\
\hline & $50 \mathrm{~m}$ continuously & $3.50 \pm 1.02 \mathrm{~A}$ & $31.50 \pm 8.20 \mathrm{AB}$ & $1.00 \pm 0.68 \mathrm{AB}$ & $63.50 \pm 7.43 \mathrm{~B}$ & $18.38 \pm 4.39 \mathrm{BC}$ & $0.75 \pm 0.41 \mathrm{~B}$ & $73.50 \pm 5.98 \mathrm{AB}$ & $346.75 \pm 7.73 \mathrm{~B}$ & $18.75 \pm 6.30 \mathrm{ABC}$ \\
\hline & $25 \mathrm{~m}$ continuously & $3.00 \pm 0.73 \mathrm{~A}$ & $38.25 \pm 10.33 \mathrm{AB}$ & $2.00 \pm 0.91 \mathrm{AB}$ & $61.13 \pm 6.07 \mathrm{~B}$ & $18.25 \pm 4.64 \mathrm{BC}$ & $1.25 \pm 0.86 \mathrm{~B}$ & $68.75 \pm 6.49 \mathrm{~B}$ & $39.00 \pm 8.43 \mathrm{~B}$ & $14.50 \pm 5.10 \mathrm{BC}$ \\
\hline & $25 \mathrm{~m}$ intermittently & $3.50 \pm 0.92 \mathrm{~A}$ & $36.63 \pm 10.79 \mathrm{AB}$ & $31.88 \pm 0.99 \mathrm{AB}$ & $60.88 \pm 7.00 \mathrm{~B}$ & $19.75 \pm 3.96 \mathrm{BC}$ & $0.63 \pm 0.50 \mathrm{~B}$ & $66.63 \pm 8.55 \mathrm{BC}$ & $45.25 \pm 9.31 \mathrm{~B}$ & $21.63 \pm 8.53 \mathrm{ABC}$ \\
\hline & Without application & $3.63 \pm 1.02 \mathrm{~A}$ & $46.00 \pm 9.80 \mathrm{~A}$ & $6.25 \pm 2.16 \mathrm{~A}$ & $78.75 \pm 6.65 \mathrm{~A}$ & $37.50 \pm 6.23 \mathrm{~A}$ & $8.25 \pm 1.97 \mathrm{~A}$ & $84.13 \pm 4.82 \mathrm{~A}$ & $63.50 \pm 9.00 \mathrm{~A}$ & $33.25 \pm 6.39 \mathrm{~A}$ \\
\hline & $\begin{array}{l}\text { Insecticide application } \\
\text { in the whole area }\end{array}$ & $2.75 \pm 0.82 \mathrm{~A}$ & $23.25 \pm 5.57 \mathrm{~B}$ & $0.25 \pm 0.16 \mathrm{~B}$ & $46.88 \pm 7.85 \mathrm{C}$ & $10.50 \pm 3.46 \mathrm{C}$ & $0.88 \pm 0.74 \mathrm{~B}$ & $55.88 \pm 6.98 \mathrm{C}$ & $24.13 \pm 6.80 \mathrm{C}$ & $8.00 \pm 3.58 \mathrm{C}$ \\
\hline \multicolumn{2}{|c|}{ C.V. $\%^{(2)}$} & 23.69 & 16.18 & 55.18 & 6.64 & 17.03 & 49.32 & 6.47 & 10.86 & 21.57 \\
\hline \multirow{6}{*}{$\ddot{m}$} & $100 \mathrm{~m}$ continuously & $1.63 \pm 0.96 \mathrm{a}$ & $22.75 \pm 7.45 \mathrm{a}$ & $0.13 \pm 0.13 \mathrm{a}$ & $40.00 \pm 6.69 \mathrm{a}$ & $1.88 \pm 0.88 \mathrm{ab}$ & $0.00 \pm 0.00 \mathrm{a}$ & $52.00 \pm 4.64 \mathrm{ab}$ & $17.63 \pm 4.33 \mathrm{a}$ & $1.75 \pm 0.62 \mathrm{a}$ \\
\hline & $50 \mathrm{~m}$ continuously & $1.75 \pm 0.86 \mathrm{a}$ & $15.00 \pm 4.90 \mathrm{ab}$ & $0.00 \pm 0.00 \mathrm{a}$ & $27.25 \pm 5.52 \mathrm{ab}$ & b $0.50 \pm 0.27 \mathrm{~b}$ & $0.00 \pm 0.00 \mathrm{a}$ & $49.00 \pm 3.84 \mathrm{ab}$ & $12.50 \pm 3.04 \mathrm{ab}$ & $0.88 \pm 0.40 \mathrm{a}$ \\
\hline & $25 \mathrm{~m}$ continuously & $1.75 \pm 0.72 \mathrm{a}$ & $16.25 \pm 5.69 \mathrm{ab}$ & $0.00 \pm 0.00 \mathrm{a}$ & $32.75 \pm 4.69 \mathrm{a}$ & $1.00 \pm 0.63 b$ & $0.00 \pm 0.00 \mathrm{a}$ & $44.63 \pm 5.32 \mathrm{bc}$ & $11.75 \pm 4.80 \mathrm{ab}$ & $0.50 \pm 0.38 \mathrm{a}$ \\
\hline & $25 \mathrm{~m}$ intermittently & $1.88 \pm 0.79 \mathrm{a}$ & $16.63 \pm 5.25 \mathrm{ab}$ & $0.00 \pm 0.00 \mathrm{a}$ & $27.38 \pm 4.02 \mathrm{ab}$ & b $1.38 \pm 0.73 \mathrm{~b}$ & $0.00 \pm 0.00 \mathrm{a}$ & $42.13 \pm 4.51 \mathrm{bc}$ & $10.50 \pm 2.95 \mathrm{~b}$ & $0.50 \pm 0.27 \mathrm{a}$ \\
\hline & Without application & $1.63 \pm 0.46 \mathrm{a}$ & $31.50 \pm 7.43 \mathrm{a}$ & $0.00 \pm 0.00 \mathrm{a}$ & $37.50 \pm 5.15 \mathrm{a}$ & $3.25 \pm 0.80 \mathrm{a}$ & $0.00 \pm 0.00 \mathrm{a}$ & $58.13 \pm 5.26 \mathrm{a}$ & $19.00 \pm 5.08 \mathrm{a}$ & $1.63 \pm 0.87 \mathrm{a}$ \\
\hline & $\begin{array}{l}\text { Insecticide application } \\
\text { in the whole area }\end{array}$ & $1.75 \pm 0.59 \mathrm{a}$ & $10.75 \pm 4.11 \mathrm{~b}$ & $0.00 \pm 0.00 \mathrm{a}$ & $16.88 \pm 5.09 \mathrm{~b}$ & $0.50 \pm 0.38 \mathrm{~b}$ & $0.00 \pm 0.00 \mathrm{a}$ & $32.38 \pm 6.50 \mathrm{c}$ & $7.13 \pm 4.44 \mathrm{~b}$ & $0.50 \pm 0.38 \mathrm{a}$ \\
\hline \multicolumn{2}{|c|}{ C.V. $\%{ }^{(2)}$} & 26.59 & 19.41 & $10.41^{-}$ & 17.21 & 31.56 & 0.00 & 10.02 & 23.50 & 33.17 \\
\hline
\end{tabular}

\section{Discussion}

Attracting and killing insects by combining bait food and a contact insecticide in a sticky formulation is one method for controlling pests (Poullot et al., 2001). The toxic bait adds a mortality factor, with a synthetic insecticide normally used (Arruda-Gatti \& Ventura, 2003). Lepidopterans have been controlled previously in cotton and soybean crops with the application of a mixture of molasses $(1 \mathrm{~L})$, water $(10 \mathrm{~L})$, and $21.5 \%$ methomyl insecticide $(30 \mathrm{~mL})$ in $5 \mathrm{~L}$ for $5 \mathrm{~m}$ of plant line bands at a distance of $50 \mathrm{~m}$ (Gallo et al., 2002). Baits with cartap insecticide at doses of 500 and $750 \mathrm{~g} \mathrm{ha}^{-1}$ (active ingredient) added to $0.5 \%$ sugar were found to effectively control the adult pink bollworm Pectinophora gossypiella population (Papa et al., 2003).

In our study, the infestation of FAW adults was affected by the year, site, and time of sowing, and, consequently, influenced the infestation of caterpillars and damage to crops. However, damage reduction after applying food bait with insecticide sprayed continuously or intermittently in bands spaced 50 and $25 \mathrm{~m}$ were similar to each other and to that after application of the methomyl-based insecticide over the entire area.

The application of the Noctovi ${ }^{\circledR} 43 \mathrm{sb}$ commercial food bait in combination with the Lannate ${ }^{\circledR}$ BR (methomyl) insecticide controlled a considerable part of the adult population of $S$. frugiperda in the treated areas, directly influencing oviposition and, consequently, caterpillar infestation, and reducing damage, as indicated by the mean scores on the Davis scale during the initial stages (V1 to V6) of the second corn crops.

Research under laboratory conditions corroborated the adult FAW mortality caused by toxic bait using the active insecticides methomyl, lambda-cyhalothrin, and spinosad together with the Noctovi ${ }^{\circledR} 43 \mathrm{sb}$ commercial food bait, with these mixtures causing $100 \%$ mortality in adults up to $5.29 \mathrm{~h}$ (Justiniano \& Fernandes, 2020).

The attracting and killing technique can be used in integrated pest management programs. However, one of the weaknesses of this method is that its efficiency decreases for high-density pests because there is greater competition for the resource (El-Sayed et al., 2009). Conversely, this technology is highly effective for 
controlling isolated and low-density populations and can add value to long-term pest management programs (Guerrero et al., 2014).

The combination of toxic baits with crops expressing the proteins Cry1A.105 + Cry2Ab was efficient in managing $S$. frugiperda caterpillars. In the present study, both technologies showed a significant reduction in damage when using the toxic bait in bands less than $50 \mathrm{~m}$ apart. However, the percentage of attacked plants in most stages remained above the recommended level for pest control.

Pest control is recommended in corn plants where $20 \%$ and $10 \%$ of plants are affected aged up to 30 days and 40-60 days, respectively (Gallo et al., 2002; Rosa \& Barcelos, 2012). Regarding the leaf damage index, pest control is recommended where $20 \%$ and $10 \%$ of plants have Davis scale scores $\geq 3$ for non-Bt and $\mathrm{Bt}$, respectively (Bernardi \& Omoto, 2018).

The presence of visible damage in areas containing Bt crops and constant reports of insect resistance to Cry1F in Brazil (Farias et al., 2014) indicate that the populations of FAW in Brazil are resistant, even to those plantations containing pyramid resistance genes (Santos-Amaya et al., 2015; Barcelos \& Angelini, 2018). On the other hand, insecticides have often shown control failures due to problems in application technology, the habit of these pests that make control difficult and, in some cases, the increase in the frequency of resistant individuals as a result of frequent spraying of insecticides with the same mode of action (Bernardi \& Omoto, 2018; Fernandes et al., 2019).

In this way, the management using toxic bait provided a reduction in the percentage of damage caused by the feeding of FAW caterpillars, resembling the standard management of the producer with the application of the insecticide in a total area that also did not keep the damage below the level of pest control threshold. For the high levels of infestation evidenced in these fields, it is necessary to use more management tools to control and maintain the levels of infestation below the control threshold.

\section{Conclusion}

The technique of attracting and killing insect pests meets and complies with the general principles of managing resistance to insecticides and Bt plants.

For $S$. frugiperda moths, the application of this control method using $1 \mathrm{~L} \mathrm{ha}^{-1}$ of the toxic bait Noctovi ${ }^{\circledR} 43 \mathrm{sb}$ commercial food bait together with the active ingredient methomyl in a dose 60 times lower $\left(20 \mathrm{~mL} \mathrm{ha}^{-1}\right)$ than the amount sprayed over the entire area, reduced the adult population, and thus significantly decreased the percentage of damage to the crop. Moreover, this effect was stronger in Bt than non-Bt corn crops.

This scenario of medium and high infestation of adults requires the use of other management tools in addition to attracting and killing techniques.

\section{Acknowledgements}

We thank the farmers Mr. José Antonio Tozzi Filho, Lúcio Damalia, and Evandro Nogueira Barbosa for providing access to their commercial plantations. We thank Dr. Marcos Vilela de Magalhães Monteiro from the Brazilian Center for Bioaeronautics (Centro Brasileiro de Bioaeronáutica-CBB) for providing some of the spray equipment and support and advice to define the methodology used in the tests. The author received no specific funding for this study.

\section{References}

Arruda-Gatti, I. C., \& Ventura, M. U. (2003). Iscas contendo cucurbitacinas para o manejo de Diabrotica spp. Semina: Ciência Agrária, 24(2), 331-336.

Barcelos, P. H. S., \& Angelini, M. R. (2018). Controle de Spodoptera frugiperda (Smith, 1797) em diferentes tecnologias bts (Bacillus thuringienses) na cultura do milho. Revista de Agricultura Neotropical, 5, 35-40. https://doi.org/10.32404/rean.v5i1.1824

Bernardi, O., \& Omoto, C. (2018). Manejo de resistência de Spodoptera frugiperda, Helicoverpa armigera e Chrysodeixes includens a inseticidas e plantas Bt (p. 9). IRAC (Comite de Ação a Resistencia a Inseticidas). Retrieved from https://www.irac-br.org/folhetos

Campanha, M. M., Cruz, J. C., Resende, A. V., Coelho, A. M., Karam, D., Silva, G. H., ... Queiroz, V. A. V. (2012). Sistema de produção integrada de milho para Região Central de Minas Gerais. Sete Lagoas, Brasil: Embrapa Milho e Sorgo.

Carnevalli, P. C., \& Florcovski, J. L. (1995). Efeito de diferentes fontes de nitrogênio em milho (Zea mays L.) sobre Spodoptera frugiperda (J. E. Smith, 1797). Ecossistema, 20, 41-49. 
CIB (Conselho de Informações Sobre Biotecnologia). (2012). O que você precisa saber sobre transgênicos. Retrieved from http://cib.org.br/wp-content/uploads/2012/08/Guia_Transgenicos_2012.pdf

Costa, L. E. C., \& Queiroz. E. S. M. (2014). Plantas geneticamente modificadas com toxinas de Bacillus thuringiensis: Uma ferramenta para conferir resistência contra insetos praga. Universitas: Ciências da Saúde, 12(2), 99-106. https://doi.org/10.5102/ucs.v12i2.2806

Cruz, I., \& Turpin, F. T. (1982). Efeito da Spodoptera frugiperda em diferentes estádios de crescimento da cultura do milho. Pesquisa Agropecuária Brasileira, 17, 335-359. https://doi.org/10.1080/0967087 99227707

Cruz, I., Figueiredo, M. L. C., Oliveira, A. C., \& Vasconcelos, C. A. (1999). Damage of Spodoptera frugiperda (Smith) in different maize genotypes cultivated in soil under three levels of aluminum saturation. International Journal of Pest Management, 45, 293-296.

Davis, F. M., Ng, S. S., \& Williams, W. P. (1992). Visual rating scales for screening whorl-stage corn for resistance to fall armyworm. Mississippi State, USA: MAFES/MSU.

Del Socorro, A. P., Gregg, P. C., \& Hawes, A. J. (2010a). Development of a synthetic plant volatile based attracticide for female noctuid moths. III. Insecticides for adult Helicoverpa armigera (HuÈbner) (Lepidoptera: Noctuidae). Australian Journal of Entomology, 49, 31-39. https://doi.org/10.1111/j.1440-6055. 2009.00735.x

Del Socorro, A. P., Gregg, P. C., Alter, D., \& Moore, C. J. (2010b). Development of a synthetic plant volatile-based attracticide for female noctuid moths I. Potential sources of volatiles attractive to Helicoverpa armigera (Hubner) (Lepidoptera: Noctuidae). Australian Journal of Entomology, 49, 10-20. https://doi.org/10.1111/j.1440-6055.2009.00733.x

El-Sayed, A. M., Suckling, D. M., Byers, J. A., Jang, E. B., \& Wearing, C. H. (2009). Potential of "lure and kill" in long-term pest management and eradication of invasive species. Journal of Economic Entomology, 102, 815-835. https://doi.org/10.1603/029.102.0301

Farias, J. R., Andow, D. A., Horikoshi, R. J., Sorgatto, R. J., Fresia, P., Santos, A. C., \& Omoto, C. (2014). Field-evolved resistance to Cry1F maize by Spodoptera frugiperda (Lepidoptera: Noctuidae) in Brazil. Crop Protection, 64, 150-158. https://doi.org/10.1016/j.cropro.2014.06.019

Fernandes, F. O., Abreu, J. A., Christ, L. M., \& Rosa, A. P. S. A. (2019). Efficacy of insecticides against Spodoptera frugiperda (Smith, 1797). Journal of Agricultural Science, 11, 494-503. https://doi.org/10.5539/ jas.v11n1p494

Fox, J., \& Weisberg, S. (2019). An R Companion to Applied Regression (3rd ed.). Thousand Oaks CA: Sage. Retrieved from https://socialsciences.mcmaster.ca/jfox/Books/Companion

Gallo, D., Nakano, O., Silveira Neto, S., Carvalho, R. P. L., Baptista, G. C., Berti Filho, E., ... Omoto, C. (2002). Entomologia Agrícola (p. 920). Piracicaba, Brazil: FEALQ.

Guerrero, A., Malo, E. A., Coll, J., \& Quero, C. (2014). Semiochemical and natural product-based approaches to control Spodoptera spp. (Lepidoptera: Noctuidae). Journal of Pest Science, 87, 231-247. https://doi.org/ 10.1007/s10340-013-0533-7

Hanway, J. J. (1971). How a corn plant develops (Special Report, 48). Iowa State University of Science and Technology, Ames, USA.

Justiniano, W., \& Fernandes, M. G. (2020). Effect of food attractants and insecticide toxicity for the control of Spodoptera frugiperda (Lepidoptera: Noctuidae) adults. Journal of Agricultural Science, 12, 129-137. https://doi.org/10.5539/jas.v12n1p129

Liu, Y., Gao, Y., Liang, G., \& Lu Y. (2017). Chlorantraniliprole as a candidate pesticide used in combination with the attracticides for lepidopteran moths. PLOS ONE, 12, e0180255. https://doi.org/10.1371/journal.pone. 0180255

Lu, Y., Wu, K., Jiang, Y., Xia, B., Li, P., Feng, H., ... Guo, Y. (2010). Mirid bug outbreaks in multiple crops correlated with wide-scale adoption of Bt cotton in China. Science, 328, 1151-1154. https://doi.org/ $10.1126 /$ science. 1187881

Monteiro, M. V. M. (2017). Controle avançado das pragas na agricultura (CAPA). Sorocaba, Brazil: Anais do V SIMPROT Faculdade de Ciências Agronômicas UNESP-Botucatu. 
Papa, G., Celoto, F. J., Takao, W., \& Prado, E. P. (2003). Efeito da isca cartap + açúcar sobre adultos lagarta rosada, Pectinophora gossypiella (Saunders, 1844; Lepidoptera: Gelechiidae). Congresso Brasileiro de Algodão. Goiânia, Brazil: Embrapa Algodão.

Poullot, D., Beslay, D., Bouvier, J. C., \& Sauphanor, B. (2001). Is attract-and-kill technology potent against insecticide-resistant Lepidoptera? Pest Management Science, 57, 729-736. https://doi.org/10.1002/ps.350

R Core Team. (2019) R: A language and environment for statistical computing. R Foundation for Statistical Computing, Vienna, Austria. Retrieved from https://www.R-project.org

Ransom, J., \& Endres, G. J. (2014). Corn growth and management quick guide. Fargo, North Dakota, USA: North Dakota State University. Retrieved from https://www.ag.ndsu.edu

Rosa, A. P. S. A., \& Barcelos, H. T. (2012). Bioecologia e controle de Spodoptera frugiperda em milho. Pelotas, Brazil: Embrapa Clima Temperado.

Santos-Amaya, O. F., Rodrigues, J. V. C., Souza, T. C., Tavares, C. S., Campos, S. O., Guedes, R. N. C., \& Pereira, E. J. G. (2015). Resistance to dual-gene Bt maize in Spodoptera frugiperda: Selection, inheritance, and cross-resistance to other transgenic events. Scientific Reports, 5, 18243. https://oi.org/10.1038/ srep18243

Souza, C. S. F., Silveira, L. C. P., Pitta, R. M., Waquil, J. M., Pereira, E. J. G., \& Mendes, S. M. (2019). Response of field populations and cry-resistant strains of fall armyworm to Bt maize hybrids and Bt-based bioinsecticides. Crop Protection, 120, 1-6. https://doi.org/10.1016/j.cropro.2019.01.001

Storer, N. P., Babcock, J. M., Schlenz, M., Meade, T., Thompson, G. D., Bing, J. W., \& Huckaba, R. M. (2010). Discovery and characterization of field resistance to $\mathrm{Bt}$ maize: Spodoptera frugiperda (Lepidoptera: Noctuidae) in Puerto Rico. Journal of Economic Entomology, 103, 1031-1038. https://doi.org/10.1603/ EC10040

Su, J. W., Fan, W. M., Wang, H. T., Xuan, W. J., \& Sheng, C. F. (2001). Technology system for adult control of pest insects. Entomological Knowledge, 38, 405-409.

Tabashnik, B. E., Brevault, T., \& Carriere, Y. (2013). Insect resistance to Bt crops: Lessons from the first billion acres. Nature Biotechnology, 31, 510-521. https://doi.org/10.1038/nbt.2597

Toscano, L. C., Calado Filho, G. C., Cardoso, A. M., Maruyama. W. I., \& Tomquelski, G. V. (2012). Impacto de inseticidas sobre Spodoptera frugiperda (Lepidoptera, Noctuidae) e seus inimigos naturais em milho safrinha cultivado em Cassilândia e Chapadão do Sul, MS. Arquivos do Instituto Biológico, 79, $223-231$. https://doi.org/10.1590/S1808-16572012000200010

Witzgall, P., Kirsch, P., \& Cork, A. (2010). Sex pheromones and their impact on pest management Journal of Chemical Ecology, 36, 80-100. https://doi.org/10.1007/s10886-009-9737-y

\section{Copyrights}

Copyright for this article is retained by the author(s), with first publication rights granted to the journal.

This is an open-access article distributed under the terms and conditions of the Creative Commons Attribution license (http://creativecommons.org/licenses/by/4.0/). 